\title{
STING and cGAS gene expressions were downregulated among HIV-1-infected persons after antiretroviral therapy
}

Lorena Leticia Peixoto de Lima, Allysson Quintino Tenório de Oliveira, Tuane Carolina Ferreira Moura, Ednelza da Silva Graça Amoras, Sandra Souza Lima, Andrea Nazaré Monteiro Rangel da Silva, Maria Alice Freitas Queiroz, Izaura Maria Vieira Cayres-Vallinoto, Ricardo Ishak and Antonio Carlos Rosário Vallinoto* (i)

\begin{abstract}
Background: The HIV-1 epidemic is still considered a global public health problem, but great advances have been made in fighting it by antiretroviral therapy (ART). ART has a considerable impact on viral replication and host immunity. The production of type I interferon (IFN) is key to the innate immune response to viral infections. The STING and cGAS proteins have proven roles in the antiviral cascade. The present study aimed to evaluate the impact of ART on innate immunity, which was represented by STING and CGAS gene expression and plasma IFN-a level.

Methods: This cohort study evaluated a group of 33 individuals who were initially naïve to therapy and who were treated at a reference center and reassessed 12 months after starting ART. Gene expression levels and viral load were evaluated by real-time PCR, $C D 4^{+}$and $\mathrm{CD} 8^{+}$T lymphocyte counts by flow cytometry, and IFN-a level by enzymelinked immunosorbent assay.

Results: From before to after ART, the $C D 4^{+} T$ cell count and the $C D 4^{+} / C D 8^{+}$ratio significantly increased $(p<0.0001)$, the $\mathrm{CD}^{+} \mathrm{T}$ cell count slightly decreased, and viral load decreased to undetectable levels in most of the group (84.85\%). The expression of STING and CGAS significantly decreased ( $p=0.0034$ and $p=0.0001$, respectively) after the use of ART, but IFN-a did not ( $p=0.1558)$. Among the markers evaluated, the only markers that showed a correlation with each other were STING and CD4 ${ }^{+} \mathrm{T}$ at the time of the first collection.
\end{abstract}

Conclusions: ART provided immune recovery and viral suppression to the studied group and indirectly downregulated the STING and CGAS genes. In contrast, ART did not influence IFN-a. The expression of STING and cGAS was not correlated with the plasma level of IFN-a, which suggests that there is another pathway regulating this cytokine in addition to the STING-CGAS pathway.

Keywords: STING, CGAS, IFN-a, Expression, HIV-1, ART

*Correspondence: vallinoto@ufpa.br; vallinoto@me.com Laboratory of Virology, Institute of Biological Sciences, Federal University of Pará (UFPA), Belém, Pará, Brazil

\section{Background}

Human immunodeficiency virus 1 (HIV-1) infection and acquired immune deficiency syndrome (AIDS) are public health problems due to their pandemic proportions. The virus infects about 37.9 million people worldwide, of which 24.5 million have access to antiretroviral therapy (ART) [1]. original author(s) and the source, provide a link to the Creative Commons licence, and indicate if changes were made. The images or other third party material in this article are included in the article's Creative Commons licence, unless indicated otherwise in a credit line to the material. If material is not included in the article's Creative Commons licence and your intended use is not permitted by statutory regulation or exceeds the permitted use, you will need to obtain permission directly from the copyright holder. To view a copy of this licence, visit http://creativecommons.org/licenses/by/4.0/. The Creative Commons Public Domain Dedication waiver (http://creativeco mmons.org/publicdomain/zero/1.0/) applies to the data made available in this article, unless otherwise stated in a credit line to the data. 
HIV-1 infects CD4 ${ }^{+} \mathrm{T}$ cells, which causes immunodeficiency characterized by the reduction in these cells counts and an increase in $\mathrm{CD}^{+}$cytotoxic $\mathrm{T}$ cells [2]. Since the discovery of AIDS, several efforts have been made to contain the spread of the virus and prevent the infected individual from developing severe immunodepression leading to death. Of all the strategies studied and applied to date, ART has had great success, and its main objective is to suppress long-term viral multiplication and preserve or restore immune function [3-5].

The innate immune response to infections is mainly based on the recognition of the so-called pathogen-associated molecular patterns (PAMPs) or damage-associated molecular patterns. Such recognition is only possible through the activity of pattern recognition receptors that are sensitive to signs of invasion by pathogenic microorganisms and cellular damage. When pattern recognition receptors recognize molecular patterns, they send a signal to stimulate the antiviral innate immune response and/or pro-inflammatory cytokine response. The action of the initial response is mainly represented by interferon (IFN)-I, macrophages, and natural killer cells [6-9].

Because nucleic acids are a key element in pathogen replication, they are one of the main groups of PAMPs recognized by Toll-like receptors, members of the RIG1-like family [10], and the stimulator of interferon genes (STING), which was identified as a new nucleic acid detector [11]. STING binds directly to dsDNA or associates with second messengers called cyclic dinucleotides (CDNs), such as c-AMP, c-GMP, c-di-AMP, or c-di-GMP [12]. By binding to DNA or CDNs, STING is activated through the association with and activation of interferon regulatory factor (IRF) 3 and IRF7, after which it stimulates the transcription of innate immunity genes such as the IFN-I gene. In a second signaling cascade, STING also activates the nuclear factor (NF) $-\mathrm{kB}$ pathway, which leads to the production of pro-inflammatory cytokines $[13,14]$. The activity of the cGMP-AMP synthase (cGAS) enzyme, which is responsible for the synthesis of the second messenger cGAMP, is essential for the detection of CDNs by STING and is therefore characterized as an essential element in the cytosolic signaling cascade by STING [15].

STING plays a major role in the production of IFN-I, as shown by both knockdown and overexpression experiments in different cells. Studies with STING-deficient animals show that they are viable but extremely sensitive to infection by a variety of DNA and RNA viruses $[11,13$, 16]. Different viruses with DNA and RNA genomes have been implicated in cGAS/STING-dependent activation, including HIV-1 [17-19]. The silencing or deficiency of cGAS or STING strongly inhibits the induction of interferons and other cytokines. Cells with mutant $c G A S$ are also unable to mount any detectable immune response against HIV infection [13, 19-22]. In addition, ART seems to interfere with $c G A S$ activity, reducing IFN-I production $[21,22]$.

The present study evaluated the influence of ART on the expression of STING and $c G A S$, the production of type I IFN, and the levels of laboratory markers often used to monitor infection $\left(\mathrm{CD}^{+}, \mathrm{CD}^{+}\right.$, and ratio of $\mathrm{CD}^{+} / \mathrm{CD}^{+} \mathrm{T}$ cells and viral load) in a cohort infected with HIV-1.

\section{Methods \\ Study population}

Sixty-two HIV-1-infected patients were initially contacted, but only 48 were eligible to start the study because they were not taking therapy. Ethnicity was not a criterion for selecting and separating patients into subgroups, since the target population is representative of the population of Belem, capital of Para State, that is composed by interethnic mixture. Likewise, transmission modes were not evaluated.

The 48 HIV-1-infected individuals, admitted to the Serviço de Assistência Especializada Casa Dia (Casa Dia Specialized Care Service), located in the municipality of Belem, Para, Brazil, were over 18 years old, and of either sex. All the patients enrolled in the present study were recently diagnosed; but did not know how long they had been infected. They were followed up for an average of 12 months from the start of therapy. At the end of the 12-month follow-up, only 33 individuals were still using ART and returned to the reference center.

The project was approved by the Research Ethics Committee of the Center for Oncology Research at the Federal University of Pará (CAAE 31446920.0.0000.0018). All subjects were duly informed of the objectives of the study, and those who agreed to participate in the study signed an informed consent form.

\section{Sample collection and storage}

Whole blood was collected in two 5-mL tubes containing $\mathrm{K}_{3}$-EDTA. The samples were placed in an appropriate container for conservation and transported to the Laboratory of Virology of the Institute of Biological Sciences of the Federal University of Pará (UFPA). A portion of each whole-blood sample was used for quantification of $\mathrm{CD}^{+}$and $\mathrm{CD}^{+} \mathrm{T}$ cells, and the other part was centrifuged for separation of plasma and cells. The plasma HIV-1 viral load and INF- $\alpha$ level were quantified, and leukocytes were stored after the addition of TRIzol to maintain RNA integrity. All samples were stored at $70{ }^{\circ} \mathrm{C}$ until use. 


\section{RNA extraction}

Total RNA was extracted from peripheral-blood leukocytes using the TRIzol ${ }^{\mathrm{TM}}$ Plus RNA Purification Kit (ThermoFisher Scientific, Waltham, Massachusetts, USA), and all steps followed the protocol recommended by the manufacturer. The concentration of extracted RNA was determined using a NanoDrop ${ }^{\text {TM }}$ fluorimeter (ThermoFisher Scientific, Waltham, Massachusetts, USA) according to the manufacturer's instructions. All total RNA samples were diluted to $50 \mathrm{ng} / \mu \mathrm{L}$ for complementary DNA (cDNA) synthesis.

\section{Reverse transcription}

The extracted RNA was converted into cDNA using the High Capacity cDNA Reverse Transcription ${ }^{\circledR}$ with RNase Inhibitor kit (Applied Biosystems, Foster City, CA, USA). For the reverse transcription reaction, a mix of $20 \mu \mathrm{L}$ was prepared, which contained $2 \mu \mathrm{L}$ of $10 \times$ RT Buffer, $0.8 \mu \mathrm{L}$ of $25 \times \mathrm{dNTP}$ Mix $(100 \mathrm{nM}), 2 \mu \mathrm{L}$ of random primer, 1 $\mu \mathrm{L}$ of MultiScribe ${ }^{\mathrm{TM}}$ Reverse Transcriptase, $1 \mu \mathrm{L}$ of RNaseOUT $^{\mathrm{TM}}$, and $3.2 \mu \mathrm{L}$ of ultra-pure water, which were provided by the kit, plus $10 \mu \mathrm{L}$ of extracted RNA. The mixture was placed in a Mastercycler Personal thermocycler (Eppendorf, Hamburg, Germany) and cycled at $25^{\circ} \mathrm{C}$ for $10 \mathrm{~min}, 37^{\circ} \mathrm{C}$ for $120 \mathrm{~min}$, and $85^{\circ} \mathrm{C}$ for $5 \mathrm{~min}$.

mRNA quantification by real-time quantitative PCR (qPCR) Initially, the standardization of qPCRs with CDNAs and probes (endogenous genes and targets) was performed to calculate the efficiency of the amplification reactions. In the standardization reactions, different concentrations of cDNA (pure and in four twofold dilutions: 1:2, 1:4, 1:8, and 1:16) were tested. All reactions were performed in plates and in triplicate, and the same cDNA (at different dilutions) was analyzed at the same time as the different probes to construct an efficiency curve to validate the $2^{-}$ $\triangle \Delta \mathrm{CT}$ computation method. All tests showed efficiency as expected $(100 \% \pm 10)$ [49].

The relative quantification of gene expression consisted of amplification of the target gene along with an endogenous normalization gene using TaqMan $^{\text {TM }}$ assays (Applied Biosystems, Foster City, CA, USA) and the StepOnePLUS $^{\mathrm{TM}}$ Real-Time PCR System (Thermo Fisher Scientific, Waltham, MA, USA). The reactions were performed in singleplex format following the manufacturer's protocol. TaqMan Gene Expression Assays were used (Hs00736955_g1 for STING, Hs02786624_g1 for cGAS, and Hs02786624_g1 for the endogenous reference gene glyceraldehyde-3-phosphate dehydrogenase). The primer and probe sequences that make up the assays are not available by Thermo Fisher Scientific (Waltham, MA, USA). For the reaction, we used $15 \mu \mathrm{L}$ of $2 \times$ TaqMan $^{\circledR}$
Universal PCR Master Mix, $1.5 \mu \mathrm{L}$ of the $20 \times$ TaqMan Gene Expression Assay, $3 \mu \mathrm{L}$ of cDNA, and $10.5 \mu \mathrm{L}$ of RNase-free water. The thermocycling conditions were $2 \mathrm{~min}$ at $50{ }^{\circ} \mathrm{C}$, followed by $10 \mathrm{~min}$ at $95^{\circ} \mathrm{C}$ and $1 \mathrm{~min}$ at $60{ }^{\circ} \mathrm{C}$.

The relative quantification of target gene expression was calculated using the comparative $\mathrm{CT}$ method with the formula $2^{-\Delta \Delta C T}$, where $\Delta \Delta C_{t}=\Delta C_{t}$ sample $-\Delta C_{t}$ reference (Life Technologies, Carlsbad, CA, USA).

\section{$\mathrm{CD}^{+}$and $\mathrm{CD}^{+} \mathrm{T}$ cell counts}

The $\mathrm{CD}^{+}$and $\mathrm{CD}^{+} \mathrm{T}$ cells were counted by flow cytometry (BD FACSCalibur ${ }^{\mathrm{TM}}$, Becton \& Dickinson) with the FACSCount ${ }^{\mathrm{TM}}$ Reagents monitoring kit, following the protocol recommended by the manufacturer (Becton \& Dickinson, San Jose, California, USA).

\section{Quantification of HIV-1 plasma viral load}

The viral load was quantified by real-time PCR using the Sample Purific CV HIV-1 extraction kit (Abbott) and the HIV-1 viral load amplification kit (Abbott, Chicago, Illinois, USA). The units used were copies/mL converted by $\log _{10}$. Both the $\mathrm{CD}^{+}$and $\mathrm{CD}^{+} \mathrm{T}$ cells and the HIV-1 viral load were quantified according to the standard set by the National Network for the Determination of CD4 ${ }^{+}$ and $\mathrm{CD}^{+} \mathrm{T}$ cells and Viral Load of the Department of HIV/AIDS and Viral Hepatitis of the Ministry of Health.

\section{Plasma quantification of IFN-I}

The levels of IFN-I (IFN- $\alpha$ ) were quantified in plasma samples with an IFN- $\alpha$ human enzyme-linked immunosorbent assay kit (Thermo Fisher Scientific, Waltham, MA USA) according to the manufacturer's recommendations.

\section{Data analysis}

All information was entered into a database in Microsoft Excel. The evaluation of the frequency of viral load before and after ART was evaluated by the $G$ test. The normality of numerical results was assessed using the Kolmogorov-Smirnov test. The $\mathrm{T}$ test or the Wilcoxon test was applied for the paired analysis of the variables $\mathrm{CD} 4^{+}$ $\mathrm{T}$ cells, $\mathrm{CD}^{+} \mathrm{T}$ cells, $\mathrm{CD} 4^{+} / \mathrm{CD}^{+} \mathrm{T}$ cell ratio, STING expression, $c G A S$ expression, and IFN- $\alpha$ level. Pearson's test or Spearman's test was used for correlation analysis. All tests were performed using the programs GraphPad Prism 5.0 and BioEstat 5.0. The quadratic regression model was performed using MINITAB 14.0 software. Associations with $\mathrm{p}<0.05$ were considered significant. 


\section{Results}

The study group consisted mostly of males (77.08\%), and the mean age was 32.6 years. Half of the individuals evaluated $(50 \%)$ had at most a complete or incomplete secondary education, and $64.44 \%$ reported having a family income between $1(R \$ 1,100)$ and 3 minimum wages. Of the initial 48 individuals, only 33 made continuous use of antiretrovirals and could be evaluated after an average of 12 months of ART. For statistical purposes, the results of the paired samples in the first (without ART) and second collections (with ART) were used.

In the evaluation of the $\mathrm{CD} 4^{+} \mathrm{T}$ cell count, a significant increase in the number of cells per $\mathrm{mm}^{3}$ was observedfrom 439 to 662 cells $/ \mathrm{mm}^{3}(\mathrm{p}<0.0001)$ (Fig. 1a). For $\mathrm{CD}^{+} \mathrm{T}$ cells, there was a slight reduction between the first and second collections $(p=0.1745)$, with medians of 956 and 928 cells $/ \mathrm{mm}^{3}$, respectively (Fig. 1b). The $\mathrm{CD}^{+} / \mathrm{CD}^{+}{ }^{+} \mathrm{T}$ cell ratio increased significantly with the use of ART, with the median increasing from 0.28 to 0.66 $(\mathrm{p}<0.0001)$ (Fig. 1c).

The HIV-1 viral load decreased between the first and second collections. Most individuals $(84.85 \%)$ started to have an undetectable viral load $(<40$ copies $/ \mathrm{mL})$ after using ART (Table 1).

The comparison of the mRNA levels of STING and $c G A S$ between the periods evaluated showed that both
Table 1 Quantification of HIV-1 viral load in individuals before and 12 months after ART

\begin{tabular}{llll}
\hline Viral load (copies/mL) & $\begin{array}{l}\text { Before ART } \\
\mathrm{n}(\%)\end{array}$ & $\begin{array}{l}\text { After ART } \\
\mathrm{n}(\%)\end{array}$ & $\mathrm{p}^{*}$ \\
\hline$<40$ & $1(3.03)$ & $28(84.85)$ & $<0.0001$ \\
$41-999$ & $3(9.09)$ & $3(9.09)$ & \\
$1000-10,000$ & $5(15.15)$ & $0(0.0)$ & \\
$>10,000$ & $24(72.73)$ & $2(6.06)$ & \\
\hline
\end{tabular}

$\mathrm{n}$; number of individuals; ${ }^{*} \mathrm{G}$ test

genes were downregulated after 12 months of therapy. The median relative STING expression value decreased from 2.50 to $0.16(\mathrm{p}=0.0034)$ (Fig. 2a). The median $c G A S$ level decreased from 6.29 to 0 ( $\mathrm{p}=0.0001$ ) (Fig. $2 \mathrm{~b}$ ).

The evaluation of the correlation between STING and cGAS mRNA levels showed a significantly positive correlation between the two markers before $(\mathrm{p}<0.0001$; Fig. 3a) and after the use of antiretroviral therapy $(\mathrm{p}=0.0058$, Fig. 3b).

The median plasma IFN- $\alpha$ level before ART was 19.57, which decreased slightly after 12 months of ART (18.26) $(\mathrm{p}=0.1558)$ (Fig. 4).

The correlations between IFN- $\alpha$ level and STING and $c G A S$ expression levels showed that there was a positive
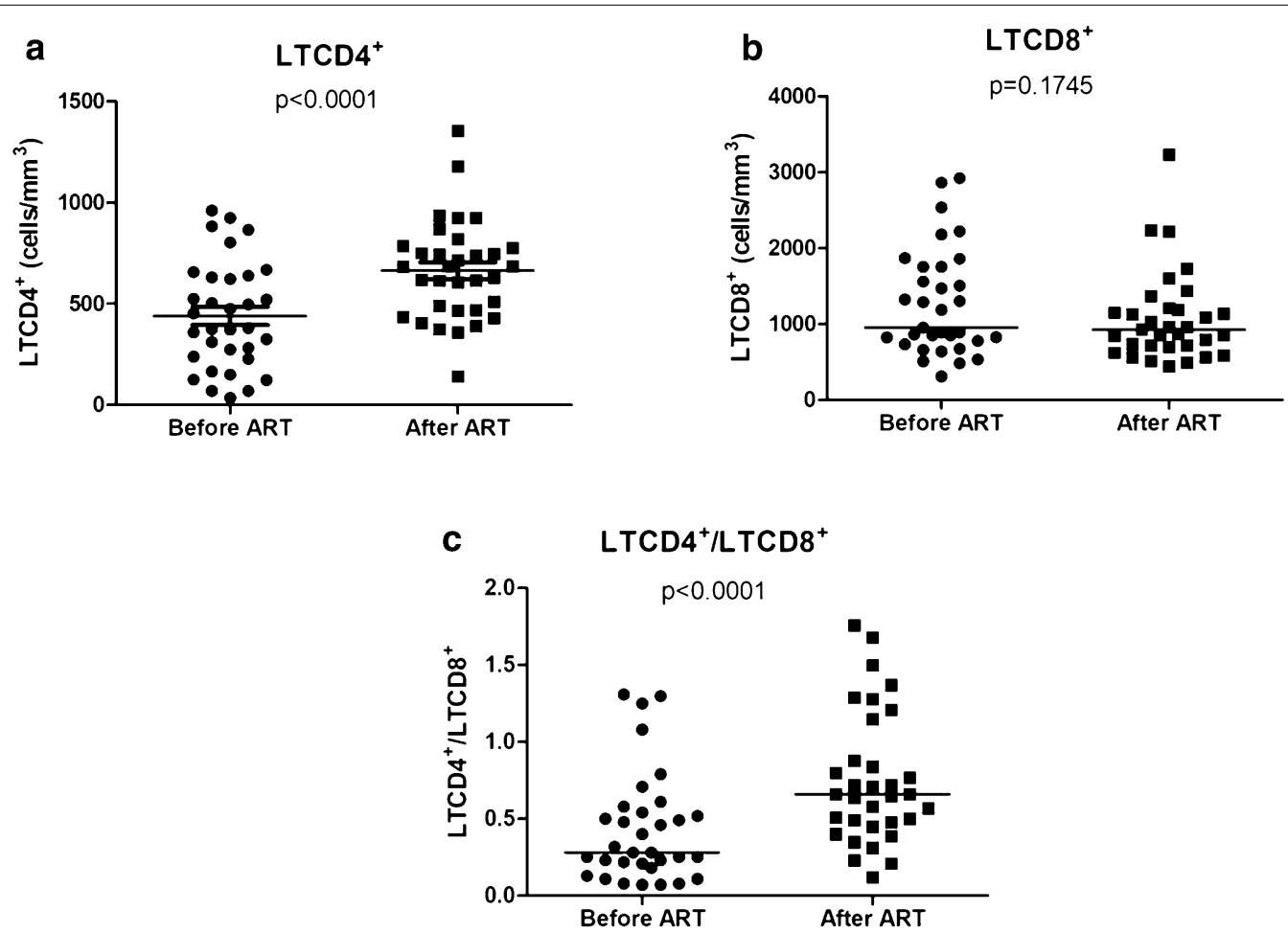

Fig. 1 Evaluation of the levels of $\mathbf{a} C D 4^{+} T$ cells, $\mathbf{b} C D 8^{+} T$ cells, and $\mathbf{c}$ the $C D 4^{+} / C D 8^{+} T$ cell ratio before and after ART 


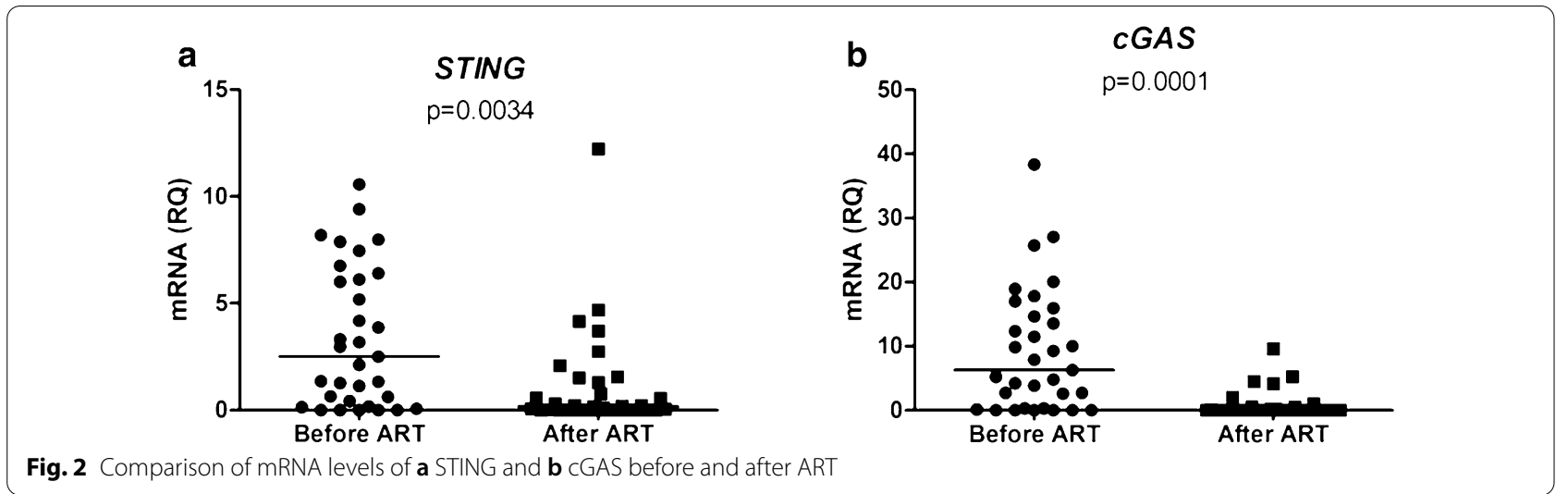

Fig. 2 Comparison of mRNA levels of a STING and $\mathbf{b}$ CGAS before and after ART
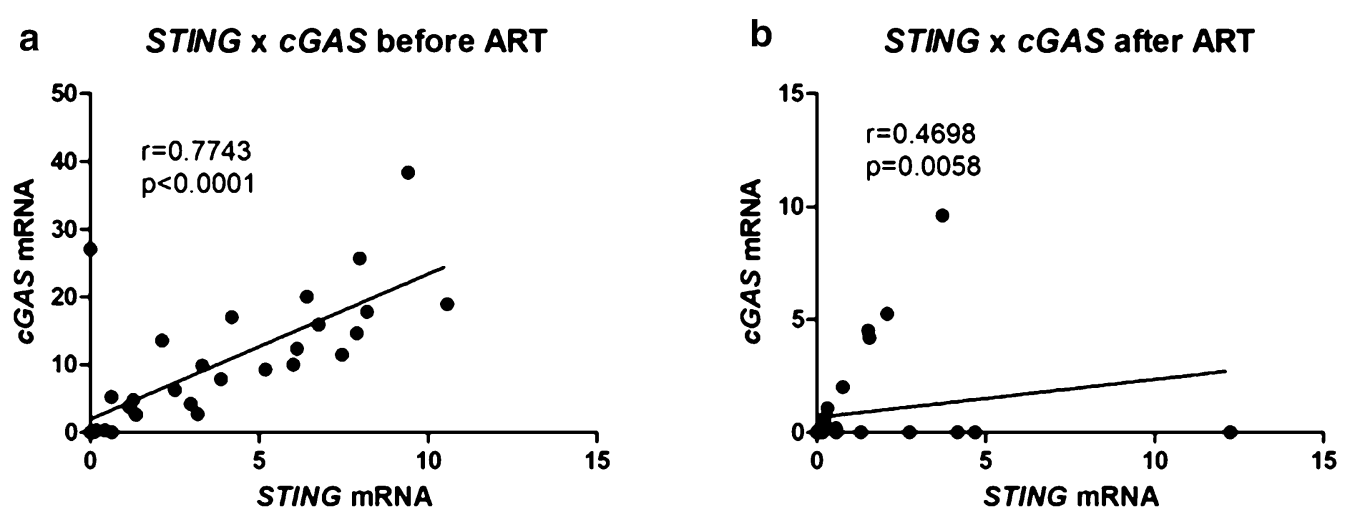

Fig. 3 Correlation between STING and CGAS mRNA levels $\mathbf{a}$ before and $\mathbf{b}$ after the use of ART

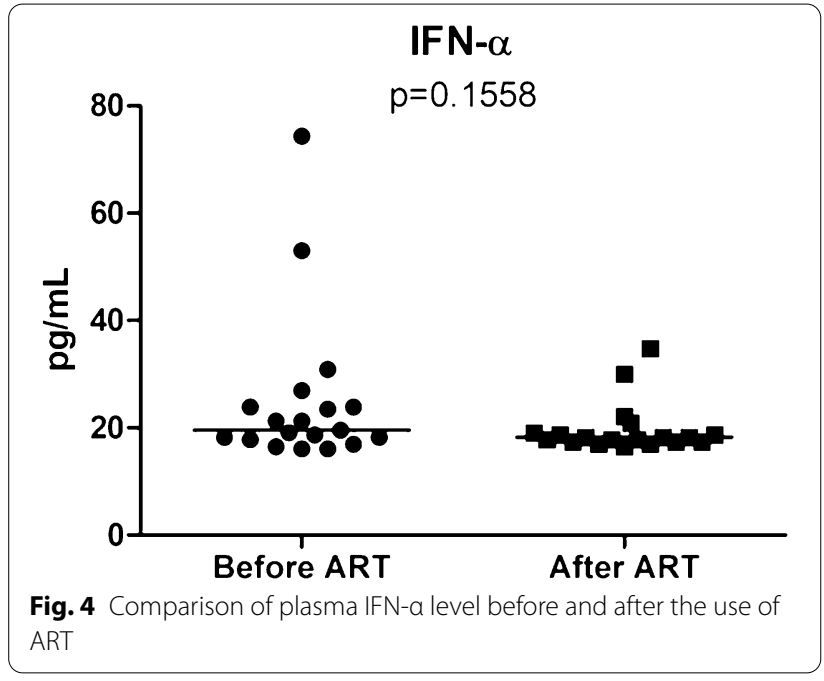

correlation trend for STING in both periods, but without statistical significance (Fig. 5a, b). For $c G A S$, the correlation with IFN- $\alpha$ showed a positive trend before the use of ART and a negative trend after its use (Fig. 5c, d). For a better understanding of the relationship between the levels of these markers before ART, the quadratic regression model was performed, which showed in more detail the distribution of the samples regarding to the levels of IFN $-\alpha$ and STING $(\mathrm{r} 2=0.87, \mathrm{p}<0.0001)$ and between IFN- $\alpha$ and cGAS $(\mathrm{R} 2=0.68, \mathrm{p}<0.0001)$ (Additional file 1).

The correlation analyses of the STING and cGAS mRNA levels with the $\mathrm{CD}^{+}$and $\mathrm{CD} 8^{+} \mathrm{T}$ cell levels are shown in Table 2. Significance was only observed for the correlation between STING and CD4 ${ }^{+}$T cells, which was negative before treatment $(\mathrm{p}=0.0463)$. The correlation between STING and CD8 ${ }^{+}$T cells remained positive in both analyses and was higher after the beginning of therapy $(\mathrm{r}=0.1678 ; \mathrm{p}=0.3505)$. Regarding the $\mathrm{CD} 4^{+} / \mathrm{CD}^{+}$ $\mathrm{T}$ cell ratio, the expression of the STING gene showed a correlation that went from negative $(r=-0.2687$, $\mathrm{p}=0.1306)$ to positive $(\mathrm{r}=0.1270, \mathrm{p}=0.4812)$ after starting ART. For the $c G A S \times \mathrm{CD}^{+} \mathrm{T}$ cell correlation analysis, $\mathrm{r}=-0.2740$ and $\mathrm{p}=0.1228$ were obtained in the first collection, while the results were $r=0.2889$ and $p=0.1030$ at the second collection. The results of the correlation of cGAS expression with $\mathrm{CD}^{+} \mathrm{T}$ cell count showed a weak 

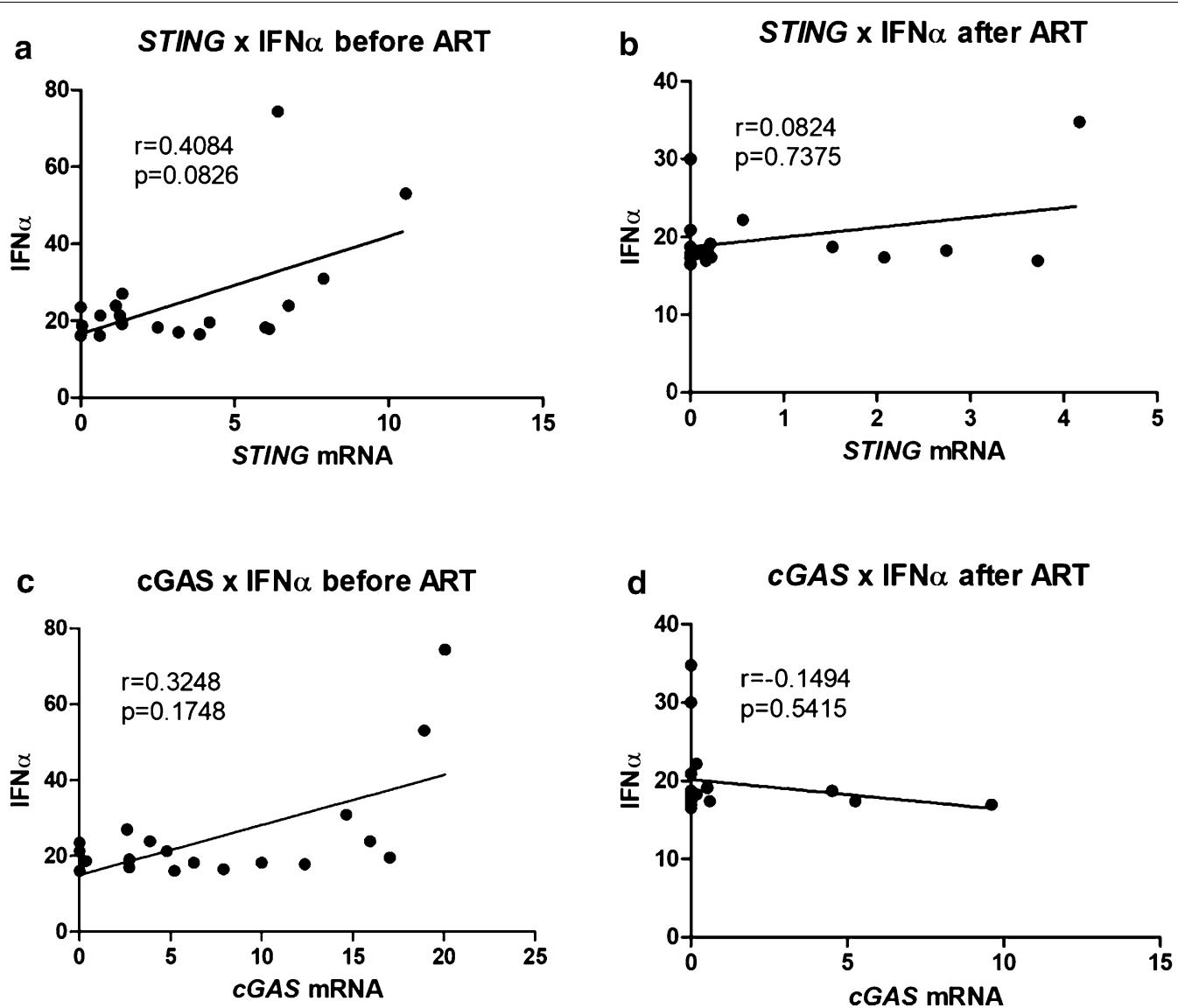

Fig. 5 Correlation between IFN-a level and STING mRNA level $\mathbf{a}$ before and $\mathbf{b}$ after ART; correlation of IFN- $\boldsymbol{a}$ and cGAS levels $\mathbf{c}$ before and $\mathbf{d}$ after ART

Table 2 Results of the correlation tests of STING and cGAS gene expression with the levels of $\mathrm{CD}^{+}$and $\mathrm{CD}^{+} \mathrm{T}$ cells and the $\mathrm{CD}^{+} / \mathrm{CD}^{+}+\mathrm{T}$ cell ratio before and after ART

\begin{tabular}{|c|c|c|c|c|}
\hline & \multicolumn{2}{|l|}{ STING } & \multicolumn{2}{|l|}{ cGAS } \\
\hline & r & $p$ value & $r$ & $p$ \\
\hline \multicolumn{5}{|l|}{ Before ART } \\
\hline $\mathrm{CD}^{+} \mathrm{T}$ cells & -0.3493 & 0.0463 & -0.2740 & 0.1228 \\
\hline $\mathrm{CD}^{+} \mathrm{T}$ cells & 0.0846 & 0.6398 & -0.1523 & 0.4133 \\
\hline $\mathrm{CD}^{+} / \mathrm{CD}^{+}{ }^{+} \mathrm{T}$ cell ratio & -0.2687 & 0.1306 & -0.1824 & 0.3096 \\
\hline \multicolumn{5}{|l|}{ After ART } \\
\hline $\mathrm{CD}^{+} \mathrm{T}$ cells & 0.2408 & 0.1771 & 0.2889 & 0.1030 \\
\hline $\mathrm{CD}^{+} \mathrm{T}$ cells & 0.1678 & 0.3505 & 0.1770 & 0.3325 \\
\hline $\mathrm{CD}^{+} / \mathrm{CD}^{+}{ }^{+} \mathrm{T}$ cell ratio & 0.1270 & 0.4812 & 0.0603 & 0.7388 \\
\hline
\end{tabular}

correlation before $(\mathrm{r}=-0.1523, \mathrm{p}=0.4133)$ and after treatment started $(\mathrm{r}=0.1770, \mathrm{p}=0.3325)$. The correlation of $c G A S$ with the CD4+/CD8 + T cell ratio was not significant but went from negative in the first collection $(\mathrm{r}=-0.1824 ; \mathrm{p}=0.3096)$ to positive in the 2 nd collection $(\mathrm{r}=0.06033 ; \mathrm{p}=0.7388)$.

\section{Discussion}

Since the advent of ART for people living with HIV, a significant reduction in AIDS-related morbidity and mortality has been observed. The best results are obtained from individuals who achieve immune recovery, which is mainly represented by the restoration of $\mathrm{CD} 4^{+} \mathrm{T}$ cell levels. Appropriate use of the therapy is also necessary for suppression of viral replication. Together, the beneficial effects of ART lead to a better clinical prognosis for patients [23, 24].

Studies evaluating the impact of ART are reasonable in relating the administration of therapy to the improvement of virologic and immunologic status and the reduction in the risk of AIDS progression. Such results have been observed since the introduction of ART in different countries and agree with the results obtained in the present study [25-28]. 
The effects of ART on innate immune markers are still not fully understood, as it is the case for the STING and cGAS molecules, which are important elements in the IFN-I production cascade that is responsible for antiviral action $[11,20]$. Therefore, the study of these markers is useful to evaluate their roles in HIV-1 infection, as well as their impact before and after the use of ART. Our results show that STING and $c G A S$ gene expression decreased after the use of ART. This result could be related to the reduction or abolition of viral replication induced by ART. A minimum amount of nucleic acid accumulation is necessary for activation of the cGAS-STING pathway [29], so if viral replication is inhibited by therapy, there will most likely be too little cDNA to induce the expression of these genes.

The activity of cGAS is essential for the detection of CDNs by STING in viral infection $[15,17]$. The correlation between STING and cGAS levels showed that before therapy there was a greater positive correlation than after the use of ART, showing that the infection induces the continuous expression of the two restriction factors for activation of innate immunity mechanisms against HIV-1 infection, while the use of HAART influenced the reduction in the levels of factors, which resulted in a reduction in the correlation between both.

Similar to what was observed in our study, Nissen et al. (2014) also reported higher levels of $c G A S$ expression in individuals who did not use ART [30]. Reverse transcriptase inhibitors promote $c G A S$ inhibition because they inhibit the formation of viral DNA which is crucial for cGAS activity [21]. These results show that a high $\mathrm{HIV}-1$ replication rate contributes to $c G A S$ gene expression. The evaluation of the impact of ART in an Ugandan cohort showed a downregulation of several antiviral response genes after starting ART, including IRF7 and OAS1, a gene which protein has structural and functional homology with $c G A S$ [31]. In a similar analysis, Li et al. (2004) also found a reduction in the expression of 26 genes after the use of ART, which, like STING and $c G A S$, were related to IFN production [32]. In this sense, the present study corroborates previous information that ART acts as a downregulator of STING and cGAS since it significantly reduces the levels of PAMPs detected by the pathway.

The activity of IFN-I in the control of viral infections is a point already widely discussed in the literature. Cytokines are considered key effector molecules in the innate immune response and have widespread effects and the ability to quickly stimulate the entire immune system [33]. In viral infections, the main molecular patterns are nucleic acids, which are a strong stimulator of the IFN-I response [10].
The activity of IFN- $\alpha$ consists of promoting an antiviral state in the host cell through restriction factors that prevent viral replication and by stimulating other immune response cells, such as natural killer cells [34]. IFN- $\alpha$ also contributes to a sustained immune activation and exacerbated inflammatory response, making for an important duality for this cytokine and making its role possibly controversial in some cases [35]. In the present study, plasma levels of IFN- $\alpha$ were slightly lower after the use of ART, but not significantly. This may be explained by the activity of other pathways acting in a cGAS-STINGindependent manner, sensors such as RIG-I [36] or TLRs (TLR7, TLR9) [10, 37] that might not have been strongly affected by ART. The production of type 1 interferons, including IFN- $\alpha$, in the immunopathogenesis of HIV-1, in addition to being related to the antiviral response, can induce inflammatory mechanisms by persistent immune activation and even T-cell exhaustion $[35,38]$, which may contribute to the progression to AIDS.

Studies such as by French et al. (2009) and Malherbe et al. (2014) found that even with virologic success and immune recovery, IFN- $\alpha$ did not undergo a significant reduction after the onset of ART $[39,40]$. This finding agrees with ours and, together, may suggest that the production of IFN- $\alpha$ after the use of ART is more related to immune activation than to antiviral activity. Therefore, it is possible that the use of antiretroviral therapy is not sufficient to completely abolish the production of immune activators as inflammatory mediators, even with therapeutic success in reducing the viral load and recovering CD4 ${ }^{+} \mathrm{T}$ cells.

The positive correlation observed between the expression of STING and $c G A S$ and the levels of interferon can be explained by the function of the STING and $c G A S$ genes, which are, respectively, an adapter and a sensor of innate immunity, parts of an important cascade that results in the production of IFN-I against viral infections, among other stimuli. With the availability of viral load for detection by the sensors, high expression of these genes and high IFN-I levels were expected in the evaluation before the start of ART [21, 41, 42]. The present study, after starting ART, IFN- $\alpha$ did not follow the same pattern of significance as STING and cGAS. A possible explanation for this may be the activity of another gene stimulated by interferon, such as Mx2 [43], IRF1 [44], Viperin, or the IFIT1, -2, or 3 gene [45], which were not evaluated in the present study.

The negative correlation observed between STING and $\mathrm{CD}^{+} \mathrm{T}$ cell level can be explained by understanding the immunological characteristics of acute HIV-1 infection without treatment. Cerboni et al. (2017) suggested that STING plays a downregulator role in the proliferation of $\mathrm{T}$ lymphocytes [46]. The evaluation of the expression 
of STING and $c G A S$ with the levels of the other immune response markers $\left(\mathrm{CD}^{+} \mathrm{T}\right.$ cells and $\mathrm{CD} 4^{+} / \mathrm{CD}^{+} \mathrm{T}$ cell ratio) suggests that these are not directly correlated. However, STING and $c G A S$ have been associated with increased stimulation of responses by $\mathrm{CD} 8^{+} \mathrm{T}$ cells $[47$, 48]. Mechanistic studies should be performed to better elucidate this relationship.

\section{Conclusions}

The use of ART provided immune recovery and viral suppression to the studied group and indirectly induced the downregulation of STING and cGAS. In contrast, ART did not affect plasma IFN- $\alpha$. The expression of STING and $c G A S$ were not correlated with plasma IFN- $\alpha$, which suggests that the STING-cGAS pathway is not the main cytokine-inducing pathway.

\begin{abstract}
Abbreviations
AIDS: Acquired immunodeficiency syndrome; ART: Antiretroviral therapy; CAMP: Cyclic adenosine monophosphate; cGAS: CGMP-AMP synthase; CGMP: Cyclic guanosine monophosphate; c-di-AMP: Cyclic dimeric adenosine monophosphate; ci-di-GMP: Cyclic dimeric guanosine monophosphate; CGAMP: Cyclic guanosine monophosphate-adenosine monophosphate: CDNA: Complementary DNA; CDN: Cyclic dinucleotide; CT: Cycle treshold; dsDNA: Double-stranded DNA; HIV-1: Human immunodeficiency virus 1; IFN: Interferon; IRF: Interferon regulatory factor; mRNA: Messenger RNA; NF-kB: Nuclear factor KB; OAS1: Oligoadenilato sintetase 1; PAMP: Pathogen-associated molecular pattern; qPCR: Quantitative polymerase chain reaction; RIG-I: Retinoic acid-inducible gene I; STING: Stimulator of interferon genes.
\end{abstract}

\section{Supplementary Information}

The online version contains supplementary material available at https://doi. org/10.1186/s12985-021-01548-6.

Additional file 1. Quadratic regression model showing in more detail the distribution of the samples in relation to the levels of (A) IFN-alpha and STING $(r 2=0.87, P<0.0001)$ and between (B) IFN-alpha and cGAS $(R 2=0.68, P<0.0001)$, before ART.

\section{Acknowledgements}

We would like to thank all participants for donating blood for our study.

\section{Authors' contributions}

Conceptualization, RI and AV; methodology, LL, AO, TM, SL and EA; validation and formal analysis, MQ, EA and LL; investigation, $L L, M Q$ and $A O$; writingoriginal draft preparation, LL, MQ, IV and AV; writing — review and editing, $A V$, $A S$ and $M Q$; supervision, $A V$ and $R l$; project administration and funding acquisition, AV, Rl and MQ. All authors read and approved the final manuscript.

\section{Funding}

This work was supported by grants from the Conselho Nacional de Desenvolvimento Científico e Tecnológico-CNPq (\#301869/2017-0), Fundação Amazônia Paraense de Amparo a Estudos e Pesquisas/Programa de Apoio aos Núcleos de Excelência-FAPESPA/PRONEX-2015 (ICAAF no. 060/2020), Coordenação de Aperfeiçoamento de Pessoal de Nível Superior-CAPES/PROCAD AMAZONIA (88881.200581/201801) and Universidade Federal do Pará (Programa de Apoio à Publicação Qualificada_PAPQ/2019).

\section{Availability of data and materials}

Data are available from the corresponding author upon reasonable request.

\section{Declarations}

\section{Ethics approval and consent to participate}

The project was approved by the Ethics Committee of the Oncology Research Center of the Universidade Federal do Pará (CAAE 66529116.4.0000.5634). All subjects were informed about the project. All participants were adults, and those who agreed to participate were asked to sign an informed consent form.

\section{Consent for publication}

Not applicable.

\section{Competing interests}

The authors declare no competing interests.

Received: 22 February 2021 Accepted: 6 April 2021

Published online: 15 April 2021

\section{References}

1. Programa das Nações Unidas sobre HIV/AIDS. Estatísticas Globais sobre HIV 2019. https://unaids.org.br/estatisticas/\#: :text=ESTAT\%C3\%8DSTI CAS\%20GLOBAIS\%20SOBRE\%20HIV\%202019\&text=770\%20000\%20\% 5B570\%20000\%E2\%80\%941,at\%C3\%A9\%200\%20fim\%20de\%202018). Acessed: 13 July 2020.

2. Pantaleo G, Fauci AS. Immunopathogenesis of HIV infection. Annu Rev Microbiol. 1996;50:825-54.

3. Dourado I, Veras MASM, Barreira D, Brito AM. Tendências da epidemia da Aids no Brasil após a terapia anti-retroviral. Rev Saúd Púb. 2006;40(6):9-17.

4. Pádua E, Almeida C, Nunes B, Cortes Martins H, Castela J, et al. Assessment of mother-to-child HIV-1 and HIV-2 transmission: an AIDS reference laboratory collaborative study. HIV Med. 2009;10(3):182-90.

5. Günthard HF, Aberg JA, Eron JJ, Hoy JF, Telenti A, Benson CA, et al. Antiretroviral treatment of adult HIV infection: 2014 recommendations of the International Antiviral Society-USA Panel. JAMA. 2014;312(4):410-25.

6. Takeuchi O, Akira S. Pattern recognition receptors and inflammation. Cell. 2010;140(6):805-20.

7. Berg RK, Melchjorsen J, Rintahaka J, Diget E, Søby S, Horan KA, et al. Genomic HIV RNA induces innate immune responses through RIG-I-dependent sensing of secondary-strutured RNA. PLOS ONE. 2012; $7(1): e 29291$

8. Carrington M, Walker BD. Immunogenetics of Spontaneous control of HIV. Annu Rev Med. 2012;63:131-45.

9. Altfeld M, Gale M Jr. Innate immunity against HIV-1 infection. Nat Immunol. 2015;16(6):554-62.

10. Cai X, Chiu YH, Chen ZJ. The CGAS-cGAMP-STING pathway of cytosolic DNA sensing and signaling. Mol Cell. 2014;54(2):289-96.

11. Ishikawa H, Barber GN. STING an endoplasmic reticulum adaptor that facilitates innate immune signaling. Nature. 2008;455(7213):674-8.

12. Barber GN. STING-dependent cytosolic DNA sensing pathways. Trend Immunol. 2012;35(2):88-93.

13. Ishikawa H, Ma Z, Barber GN. STING regulates intracellular DNAmediated, type I interferon-dependent innate immunity. Nature. 2009;461 (7265):788-92.

14. Abe T, Barber GN. Cytosolic-DNA-mediated, STING-dependent proinflammatory gene induction necessitates canonical NF-KB activation through TBK1. J Virol. 2014;88(10):5328-41.

15. Xiao TS, Fitzgerald KA. The CGAS-STING pathway for DNA sensing. Mol Cell. 2013;51(12):135-9.

16. Konno H, Barber GN. The STING controlled cytosolic-DNA activated innate immune pathway and microbial disease. Microb Infect. 2014;16(12):998-1001.

17. Lam E, Stein S, Falck-Pedersen E. Adenovirus detection by the cGAS/ STING/TBK1 DNA sensing cascade. J Virol. 2014;88(2):974-81.

18. Sunthamala N, Thierry F, Teissier S, Pientong C, Kongyingyoes B, Tangsiriwatthana T, et al. E2 proteins of high-risk human papillomaviruses downmodulate STING and IFN-k transcription in keratinocytes. PLOS ONE. 2014;9(3):e91473. 
19. Schoggins JW. Interferon-stimulated genes: roles in viral pathogenesis. Curr Opin Virol. 2014;6:40-6.

20. Rasaiyaah J, Tan CP, Fletcher AJ, Price AJ, Blondeau C, Hilditch L, et al. HIV-1 evades innate immune recognition through specific cofactor recruitment. Nature. 2013;503(7476):402-5.

21. Gao D, Wu J, Wu YT, Du F, Aroh C, Yan N, et al. Cyclic GMP-AMP synthase is an innate immune sensor of HIV and other retroviruses. Science. 2013;341(6148):903-6.

22. Vermeire J, Roesch F, Sauter D, Rua R, Hotter D, Van Nuffel A, et al. HIV triggers a cGAS-dependent, Vpu- and Vpr-regulated type i interferon response in CD4+ T CELLS. Cell Rep. 2016;17(2):413-24.

23. Autran B, Carcelain G, Li TS, Blanc C, Mathez D, Tubiana R, et al. Positive Effects of Combined Antiretroviral Therapy on CD4+ T Cell Homeostasis and Function in Advanced HIV Disease. Science. 1997:277(5322):112-6.

24. Gunda DW, Kilonzo SB, Kamugisha E, Rauya EZ, Mpondo BC. Prevalence and risk factors of poor immune recovery among adult HIV patients attending care and treatment centre in northwestern Tanzania following the use of highly active antiretroviral therapy: a retrospective study. BMC Res Not. 2017;10(1):197.

25. Gulick RM, Mellors JW, Havlir D, Eron JJ, Gonzalez C, Mcmahon D, et al. Treatment with indinavir, zidovudine, and lamivudine in adults with human immunodeficiency virus infection and prior antiretroviral therapy. N Engl J Med. 1997;337(11):734-9

26. Erb P, Battegay M, Zimmerli W, Rickenbach M, Egger M. Effect of antiretroviral therapy on viral load, CD4 cell count, and progression to acquired immunodeficiency syndrome in a community human immunodeficiency virus-infected cohort. Arch Intern Med. 2000;160(11):1134-40.

27. May MT, Sterne JA, Costagliola D, Sabin CA, Philips AN, Justice AC, et al. Antiretroviral Therapy (ART) Cohort Collaboration. HIV treatment response and prognosis in Europe and North America in the first decade of highly active antiretroviral therapy: a collaborative analysis. Lancet. 2006;368(9534):451-8

28. Pai NP, Estes M, Moodie EE, Reingold AL, Tulsky JP. The impact of antiretroviral therapy in a cohort of HIV infected patients going in and out of the San Francisco county jail. PLoS ONE. 2009;4(9):e7115.

29. Luecke S, Holleufer A, Christensen MH, Jønsson KL, Boni GA, Sørensen LK, et al. cGAS is activated by DNA in a length-dependent manner. EMBO Rep. 2017:18(10):1707-15.

30. Nissen SK, Højen JF, Andersen KL, Kofod-Olsen E, Berg RK, Paludan SR, et al. Innate DNA sensing is impaired in HIV patients and IFI16 expression correlates with chronic immune activation. Clin Exp Immunol. 2014:177(1):295-309.

31. Boulware DR, Meya DB, Bergemann TL, Williams D, Vlasova-St Louis IA, Rhein J, et al. Antiretroviral therapy down-regulates innate antiviral response genes in patients with AIDS in sub-saharan Africa. J Acquir Immun Defic Syndr. 2010;55(4):428-38.

32. Li Q, Schacker T, Carlis J, Beilman G, Nguyen P, Haase AT. Functional genomic analysis of the response of HIV-1-infected lymphatic tissue to antiretroviral therapy. J Infect Dis. 2004;189(4):572-82.

33. Wang B, Kang W, Zuo J, Kang W, Sun Y. The Significance of Type-I Interferons in the Pathogenesis and Therapy of Human Immunodeficiency Virus 1 Infection. Front Immunol. 2017;8:1431.

34. Soper A, Kimura I, Nagaoka S, Konno Y, Yamamoto K, Koyanagi Y, et al. Type I Interferon Responses by HIV-1 Infection: Association with Disease Progression and Control. Front Immunol. 2018:8:1823.
35. Utay NS, Douek DC. Interferons and HIV infection: the good, the bad, and the ugly. Path Immun. 2016;1 (1):107-16.

36. Solis M, Nakhaei P, Jalalirad M, Lacoste J, Douville R, Arguello M, et al. RIGI-mediated antiviral signaling is inhibited in HIV-1 infection by a proteasemediated sequestration of RIG-I. J Virol. 2010;85(3):1224-36.

37. Rigby RE, Webb LM, Mackenzie KJ, LiY, Leitch A, Reijns MA, et al. RNA:DNA hybrids are a novel molecular pattern sensed by TLR9. EMBO J. 2014;33(6):542-58.

38. Zhao B, Shu C, Gao X, Sankaran B, Du F, Shelton CL, et al. Structural basis for concerted recruitment and activation of IRF-3 by innate immune adaptor proteins. Proc Natl Acad Sci USA. 2016;113(24):E3403-3412.

39. French MA, King MS, Tschampa JM, Da Silva BA, Landay AL. Serum immune activation markers are persistently increased in patients with HIV infection after 6 years of antiretroviral therapy despite suppression of viral replication and reconstitution of CD4+ T cells. J Infect Dis. 2009:200(8):1212-5.

40. Malherbe G, Steel HC, Cassol S, De Oliveira T, Seebregts CJ, Anderson R, et al. Circulating biomarkers of immune activation distinguish viral suppression from nonsuppression in HAART-treated patients with advanced HIV-1 subtype C infection. Mediat Inflamm. 2014:2014:198413.

41. Barber GN. Cytoplasmic DNA innate immune pathways. Immunol Rev. 2011;243(1):99-108.

42. Stavrou S, Blouch K, Kotla S, Bass A, Ross SR. Nucleic acid recognition orchestrates the anti-viral response to retroviruses. Cell Host Microb. 2015;17(4):478-88.

43. Kane M, Yadav SS, Bitzegeio J, Kutluay SB, Zang T, Wilson SJ, et al. MX2 is an interferon-induced inhibitor of HIV-1 infection. Nature. 2013;502(7472):563-6.

44. Sivro A, Su RC, Plummer FA, Ball TB. HIV and interferon regulatory factor 1: a story of manipulation and control. AIDS Res Hum Retrov. 2013:29(11):1428-33.

45. Nasr N, Alshehri AA, Wright TK, Shahid M, Heiner BM, Harman AN, et al. Mechanism of Interferon-Stimulated Gene Induction in HIV-1-Infected Macrophages. J Virol. 2017;91(20):e00744-e817.

46. Cerboni S, Jeremiah N, Gentili M, Gehrmann U, Conrad C, Stolzenberg MC, et al. Intrinsic antiproliferative activity of the innate sensor STING in T lymphocytes. J Exp Med. 2017;214(6):1769-85.

47. Martin-Gayo E, Buzon MJ, Ouyang Z, Hickman T, Cronin J, Pimenova D, et al. Potent cell-intrinsic immune responses in dendritic cells facilitate HIV-1-specific T cell immunity in HIV-1 elite controllers. PLoS Pathog. 2015;11(6):e1004930

48. Maelfait J, Bridgeman A, Benlahrech A, Cursi C, Rehwinkel J. Restriction by SAMHD1 limits CGAS/STING-dependent innate and adaptive immune responses to HIV-1. Cell Rep. 2016;16(6):1492-501.

49. Livak KJ, Schmittgen TD. Analysis of relative gene expression data using real-time quantitative PCR and the 2(-Delta Delta C(T)) Method. Methods. 2001:25(4):402-8

\section{Publisher's Note}

Springer Nature remains neutral with regard to jurisdictional claims in published maps and institutional affiliations.

Ready to submit your research? Choose BMC and benefit from

- fast, convenient online submission

- thorough peer review by experienced researchers in your field

- rapid publication on acceptance

- support for research data, including large and complex data types

- gold Open Access which fosters wider collaboration and increased citations

- maximum visibility for your research: over 100M website views per year

At BMC, research is always in progress.

Learn more biomedcentral.com/submissions 